\title{
ATPase activity in macula densa cells of the rabbit kidney
}

\author{
Jürgen Schnermann ${ }^{1}$ and Diana Marver ${ }^{2}$ \\ 1 Physiologisches Institut der Universität München, Pettenkoferstrasse 12, D-8000 München 2, Federal Republic of Germany \\ 2 Departments of Internal Medicine and Biochemistry, University of Texas Health Science Center, Southwestern Medical School, \\ Harry Hines Boulevard, Dallas, TX 75235, USA
}

\begin{abstract}
Na-K - and Mg-activated ATPase activities were determined in maculae densae and glomeruli dissected from both superficial and juxtamedullary nephrons of normal rabbits, using an ultramicro method including a cycling reaction. Activities were expressed as $P_{i}$ generated per macula densa or per glomerulus and normalized for tissue volume. Results indicate that the mean volume of superficial and juxtamedullary macula densa samples was not statistically different, while glomeruli from deep nephrons had sample volumes that were $29 \%$ larger than those from superficial nephrons $(P<0.001)$. Correcting for volume both superficial and juxtamedullary macula densa samples had an Na-KATPase activity of $0.37 \pm 0.21 \mathrm{fmol} \cdot \mathrm{h}^{-1} \cdot\left(\mu \mathrm{m}^{3}\right)^{-1}$. MgATPase activity in both pools was also similar [0.41 \pm 0.07 and $\left.0.52 \pm 0.1 \mathrm{fmol} \cdot \mathrm{h}^{-1} \cdot\left(\mu \mathrm{m}^{3}\right)^{-1}\right]$. Na-K-ATPase activity in macula densa cells is estimated to be about $1 / 40$ th the activity of surrounding cortical thick ascending limb cells. Total glomerular ATPase per unit volume was significantly higher in glomeruli from superficial than from deep nephrons $\left[0.41 \pm 0.04\right.$ vs. $0.28 \pm 0.04 \mathrm{fmol} \cdot \mathrm{h}^{-1} \cdot\left(\mu \mathrm{m}^{3}\right)^{-1}$, $P<0.05]$. There was no statistically significant activity of Na-K-ATPase in either superficial or deep glomeruli. These results suggest that in contrast to previous reports, the macula densa contains Na-K-ATPase, but at a low level relative to surrounding tubular cells. Further, in normal rabbits, this activity is invariant in superficial and juxtamedullary samples.
\end{abstract}

Key words: Na-K-ATPase - Mg-ATPase - Glomerulus Macula densa

\section{Introduction}

The macula densa segment represents a small cell plaque with a diameter of approximately $50 \mu \mathrm{m}$ surrounded by cells of the thick ascending limb. Application of biochemical techniques to characterize this nephron segment is therefore complicated by the excessively low amounts of tissue available for enzymatic analysis. Hence, most of the available information about the enzymatic equipment of the macula densa cells has been deduced from the application of histochemical methods. Beeuwkes and Rosen (1980) have

Offprint requests to: J. Schnermann's present address: University of Michigan Medical School, Department of Physiology, Ann Arbor, MI 48109, USA used the PNPP method of Ernst (1972) to assess macula densa Na-K-ATPase activity and concluded that these cells do not possess this enzyme in measurable quantities. Such a conclusion would affect possible explanations for macula densa-mediated mechanisms such as tubuloglomerular feedback or renin secretion. Both processes have been postulated to be governed in part by $\mathrm{NaCl}$ transport across macula densa cells (Schnermann and Briggs 1982; Vander 1967).

An approach to microenzymatic analysis of dissected macula densae has recently been outlined by Norgaard (1979) and applied to the determination of glucose-6phosphate-dehydrogenase activity in these cells. Using his technique of isolating macula densa segments we have reexamined the question of the presence of Na-K-ATPase in macula densa cells by applying a microenzymatic assay that includes a cycling reaction. Our data show that Na-KATPase activity is present in macula densa cells, even though one can estimate that the activity is substantially lower than in other segments of the nephron.

\section{Methods}

Kidneys from three anesthetized New Zealand white rabbits $(1-2 \mathrm{~kg})$ were excised and rapidly frozen in acetone/dry ice. Using a scalpel blade, cortical tissue blocks, approximately $2 \times 2 \mathrm{~mm}$ in size, were fractured from the frozen kidneys. The blocks were mounted on the microtome holders with the surface side up for superficial sections and with the surface side down for sections from the juxtamedullary cortex. Serial sections of $15 \mu \mathrm{m}$ thickness to a depth of approximately $400 \mu \mathrm{m}$ were made in a cryotome at $-20^{\circ} \mathrm{C}$. Without thawing, the sections were transferred into vacuum flasks containing aluminum holders (Ace Glass Inc, Vineland, NJ, USA), and freeze-dried at $-40^{\circ} \mathrm{C}$ (Lowry and Passonneau 1972). After lyophilization, the flasks were stored at $-80^{\circ} \mathrm{C}$ until the sections were used for ATPase assay.

Dissection. For each assay, one flask was brought to room temperature and the sections were transferred into a drop of water-equilibrated mineral oil on a glass slide. The sections were inspected at a magnification of $150 \times$. The macula densa was identified from its position at the vascular pole of the glomerulus, from the greater cell height compared to surrounding cells and from the flattened appearance at the point of glomerular contact which resulted in a triangular rather than round tubular circumference. The frequency of 
a macula densa which met all three criteria was variable, on average not more than one per section. To isolate the macula densa and its glomerulus, the tissue was removed from the section by using sharpened glass capillaries (tip diameter $12-15 \mu \mathrm{m})$ guided by micromanipulators. By holding the tissue with one capillary, the macula densa segment was then isolated by using the sharpened end of the other capillary as a cutting instrument. In general, the neighbouring thick ascending limb epithelium on both sides of the macula was sheared off first followed by the connections to the glomerulus. In a given assay 6-8 macula densa segments and as many glomeruli were dissected. The isolated pieces were placed on a clean part of the glass slide and their position was marked with a pen on the bottom of the slide. After completion of the dissection, the isolated segments were photographed using a Zeiss Standard microscope (Carl Zeiss Inc., New York, NY, USA) fitted with Planapochromat optics $(630 \times)$, phase contrast, and an Olympus (Lake Success, New York, NY, USA), OM-1 $35 \mathrm{~mm}$ camera. In addition, fragments of tubules were placed on their sides and photographed for determination of the slice thickness. To standardize the measurements, a commercial grid (calibrated in microns) was photographed and processed along with the tissue samples.

ATPase determination. By using a hypodermic needle sharpened to a fine point and a $1 \mathrm{~cm}^{3}$ syringe as a holder, the tissue was picked up under optical control, and transferred into the buffer deposited in individual wells of a teflon block (Lowry and Passonneau 1972). The buffer droplet containing the tissue was then covered with oil to prevent evaporation. The successful transfer of glomeruli could always be optically verified, but maculae densae were often not visible in the buffer solution. In such a case the transfer was marked as questionable; when the ATPase activity was determined to be zero, values of samples associated with questionable transfer were discarded. The frequency of such samples was about 1 in 10 maculae densae. In all cases the needle was inspected after transfer for absence of tissue fragments. Total and Mg-ATPase activity were measured with the microenzymatic recycling assay originally described by Lowry and Passonneau (1972) and adapted by other investigators for renal tubules (Petty et al. 1981; Schmidt and Dubach 1970; Schmidt et al. 1974).

Although the assay has been detailed previously (Petty et al. 1981), some changes in volume and concentration require a brief description. Details on the washing procedures required for added bovine serum albumin (BSA), glucose-6-phosphate dehydrogenase (G6PDH), phosphorylase a, phosphoglucomutase (PGM) and glutamate dehydrogenase $(\mathrm{GDH})$ are not given here since they were identical to those used earlier (Petty et al. 1981). For measurement of total ATPase, tissue was transferred into $108 \mathrm{nl}$ of buffer A (200 mM Tris- $\mathrm{HCl}$, pH 7.4; $106 \mathrm{mM} \mathrm{NaCl} ; 10 \mathrm{mM} \mathrm{KCl}$; $6 \mathrm{mM} \mathrm{MgCl}_{2} ; 0.2 \mathrm{mM}$ EDTA and $0.2 \mathrm{~g} / \mathrm{dl} \mathrm{BSA}$ ) and for measurement of Mg-ATPase, into $108 \mathrm{nl}$ of buffer $\mathrm{A}^{\prime}$ (Tris$\mathrm{HCl} 200 \mathrm{mM}$; $\mathrm{NaCl} 106 \mathrm{mM} ; \mathrm{MgCl}_{2} 6 \mathrm{mM}$; EDTA $0.2 \mathrm{mM}$; ouabain $2 \mathrm{mM}$ and BSA $0.2 \mathrm{~g} / \mathrm{dl}$ ). After completion of the transfer the teflon block was cooled to ice temperature. At the same time, $\mathrm{P}_{\mathrm{i}}$ standards $\left(\mathrm{KH}_{2} \mathrm{PO}_{4}\right)$ were added with the same pipette to both buffer A and $\mathrm{A}^{\prime}$. Six standards in duplicate were used in each assay, covering the range from 10.8 to $108.3 \times 10^{-12} \mathrm{~mol}$ of added $\mathrm{P}_{\mathrm{i}}$ per well. Nonenzymatic hydrolysis of ATP was also measured by adding ATP to duplicates of buffer $\mathrm{A}$ and $\mathrm{A}^{\prime}$. The ATPase reaction was started in tissue samples by rapid addition of $108 \mathrm{nl}$ of a $6 \mathrm{mM}$ ATP solution. The Teflon blocks were then transferred onto sand equilibrated at $37^{\circ} \mathrm{C}$, and incubated for 30 to $60 \mathrm{~min}$. The ATPase reaction was terminated by heating the teflon block to $100^{\circ} \mathrm{C}$ for $5 \mathrm{~min}$ in a Multi-Blok heater (Lab-Line Instruments, Melrose Park, IL, USA).

After cooling the blocks to room temperature, the coupling reaction was started by adding $1,430 \mathrm{nl}$ of a solution (solution B) containing $50 \mathrm{mM}$ imidazole- $\mathrm{HCl}(\mathrm{pH} 6.9)$, $66 \mu \mathrm{M}$ NADP, $10 \mu \mathrm{M} 5^{\prime}$-AMP, $1 \mathrm{mM}$ EDTA, $0.5 \mathrm{mM}$ $\mathrm{MgCl}_{2}, 0.08 \mathrm{~g} / \mathrm{dl}$ glycogen, $3 \mu \mathrm{g} / \mathrm{ml}$ G6PDH, $9 \mu \mathrm{g} / \mathrm{ml}$ PGM, $100 \mu \mathrm{g} / \mathrm{ml}$ phosphorylase a, and $0.05 \mathrm{~g} / \mathrm{dl}$ BSA. Phosphorylase and glycogen were activated for this reaction as described previously (Petty et al. 1981). Before adding solution B, its efficiency to convert $P_{i}$ to NADPH was tested by adding $8 \mu \mathrm{l}$ of a $1 \mathrm{mM} \mathrm{KH}_{2} \mathrm{PO}_{4}$ solution to $350 \mu \mathrm{l}$ of solution $\mathrm{B}$ and observing the rate of the increase in optical density at $340 \mathrm{~nm}$. Incubation time in the ultramicroassay at $37^{\circ} \mathrm{C}$ was based on the time required to bring the macroreaction to completion (usually between 20 and $50 \mathrm{~min}$ ). Following $\mathrm{P}_{\mathrm{i}}$ dependent generation of NADPH in this reaction, the excess NADP in reaction B was subsequently destroyed by adding $1,430 \mathrm{nl}$ of $0.17 \mathrm{n} \mathrm{NaOH}$ and heating to $80^{\circ} \mathrm{C}$ for $30 \mathrm{~min}$.

Enzymatic cycling was initiated by adding $108 \mathrm{nl}$ from each well to $50 \mu$ lof the enzymatic cycling solution (solution C) kept in $1.5 \mathrm{ml}$ snap-capped centrifuge tubes within an ice-water bath. Solution C contained $100 \mathrm{mM}$ Tris- $\mathrm{HCl}$ $(\mathrm{pH}$ 8), $5 \mathrm{mM}$ glucose-6-phosphate, $5 \mathrm{mM}$ alphaketoglutarate, $20 \mathrm{mM} \mathrm{NH}_{4}$ acetate, $0.3 \mathrm{mM}$ 5'-ADP, $3 \mu \mathrm{g}$ / $\mathrm{ml} \mathrm{G6PDH}$, and $100 \mu \mathrm{g} / \mathrm{ml} \mathrm{GDH}$, and $0.02 \mathrm{~g} / \mathrm{dl}$ BSA. The samples were incubated at $37^{\circ} \mathrm{C}$ for $45 \mathrm{~min}$ and the reaction terminated by placing the tubes in a boiling water bath for $5 \mathrm{~min}$.

After cooling, $1 \mathrm{ml}$ of the indicator solution (solution D) was added to each tube. This solution contained $20 \mathrm{mM}$ Tris- $\mathrm{HCl}\left(\mathrm{pH}\right.$ 8), $0.1 \mathrm{mM}$ EDTA, $60 \mathrm{mM} \mathrm{NH}_{4}$ acetate, $3 \mu \mathrm{M}$ $\mathrm{MgCl}_{2}, 0.2 \mathrm{mM}$ NADP, $1 \mu \mathrm{g} / \mathrm{ml}$ 6-phosphogluconate-dehydrogenase and $0.05 \mathrm{~g} / \mathrm{dl}$ BSA. Following incubation at $37^{\circ} \mathrm{C}$ for $30 \mathrm{~min}$, fluorescence was measured in a Zeiss PMQ III fluorometer (Carl Zeiss Inc) with an excitation wavelength of $340 \mathrm{~nm}$. ATPase activity was determined by comparing fluorescence in samples with the simultaneously measured fluorescence in $P_{i}$ standards. $P_{i}$ formed by nonenzymatic hydrolysis of ATP was subtracted to obtain enzyme dependent $P_{i}$ generation. Enzymatic and nonenzymatic hydrolysis of ATP did not exceed 5\% of total substrate present.

To obtain a morphological correlate of tissue mass per assayed sample, the photographed tissue segments were cut out, the paper weighed and the tissue area determined from the weight and the area/weight ratio of a standard area cut out from the same photographic paper. The volume of the tissue was then calculated by multiplying area and photographically determined slice thickness.

\section{Results}

In preliminary experiments, total ATPase activity was measured in microdissected lyophilized collecting tubules kept in mineral oil for $60-80 \mathrm{~min}$ at room temperature before assay, and compared to tubules unexposed to oil. Total ATPase activity averaged $11.5 \pm 2.17 \mathrm{pmol} \mathrm{P}_{\mathrm{i}} \cdot \mathrm{mm}^{-1}$ $\mathrm{min}^{-1}$ in control tubules $(n=9)$ and $10.6+1.62 \mathrm{pmol}$ 


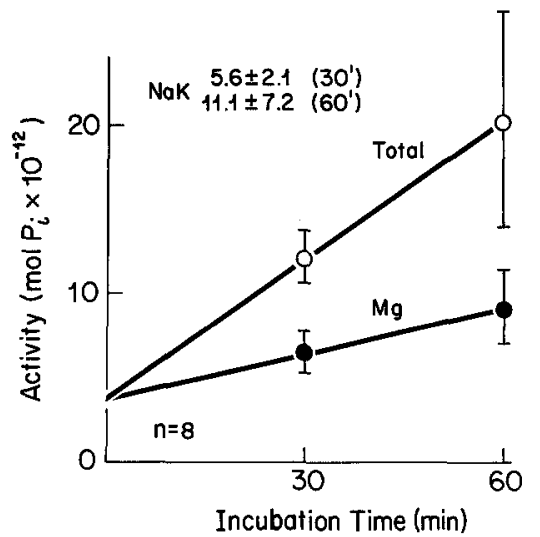

Fig. 1. ATPase activity in macula densa segments as a function of time. Macula densa obtained from superficial nephrons were incubated at $37^{\circ} \mathrm{C}$ for either 30 or $60 \mathrm{~min}$. $\mathrm{P}_{\mathrm{i}}$ present at time zero represents tissue phosphate. Values are means $\pm \mathrm{SE}$

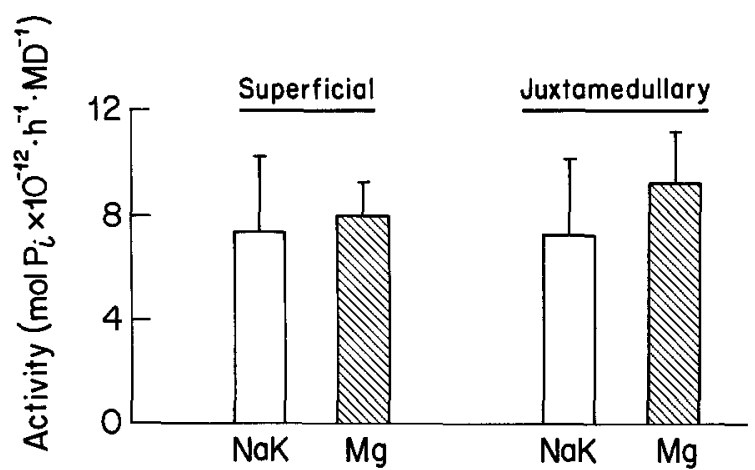

Fig. 2. $\mathrm{Na}-\mathrm{K}$ - and $\mathrm{Mg}$-ATPase activities in macula densa (MD) obtained from both superficial and juxtamedullary nephrons. Values shown are ATPase activities per macula densa $\pm S E$. The number of samples varied from $18-20$ per group

$P_{i} \cdot \mathrm{mm}^{-1} \cdot \min ^{-1}$ in oil treated tubules $(n=7)$, demonstrating that exposure of tissue to mineral oil does not affect ATPase activity. This agrees with the experiences of Norgaard (1979) and Lowry and Passonneau (1972) with regard to the assay of several other enzymes exposed or unexposed to oil. Collecting tubules rather than macula densa segments were used for this control, as it is impossible to morphologically detect the limits of the plaque in freezedried sections in the absence of oil. Figure 1 shows that total and Na-K-ATPase activity of dissected maculae densae increased in a linear fashion when tissue was incubated in the ATPase reaction for 30 or $60 \mathrm{~min}$. Thus, our normal incubation time of 45 min yielded values for $P_{i}$ well within the linear range of the assay.

Measurements of ATPase activities in isolated macula densa segments of superficial and juxtamedullary nephrons are summarized in Fig. 2. In superficial nephrons total ATPase activity was $15.4 \pm 2.41 \mathrm{pmol} \mathrm{P}_{\mathrm{i}} \cdot \mathrm{h}^{-1}(n=20)$ and Mg-ATPase activity was $8.0 \pm 1.32 \mathrm{pmol} \mathrm{P}_{\mathrm{i}} \cdot \mathrm{h}^{-1}(n=18)$. Thus, Na,K-ATPase activity averaged $7.4 \pm 2.83 \mathrm{pmol}$ $\mathrm{P}_{\mathrm{i}} \cdot \mathrm{h}^{-1}$ (standard error calculated according to Doucet et al. 1979). Results from juxtamedullary nephrons were not significantly different. With a total ATPase of $16.2 \pm 2.16 \mathrm{pmol}_{\mathrm{i}} \cdot \mathrm{h}^{-1}(n=20)$ and a Mg-ATPase activity

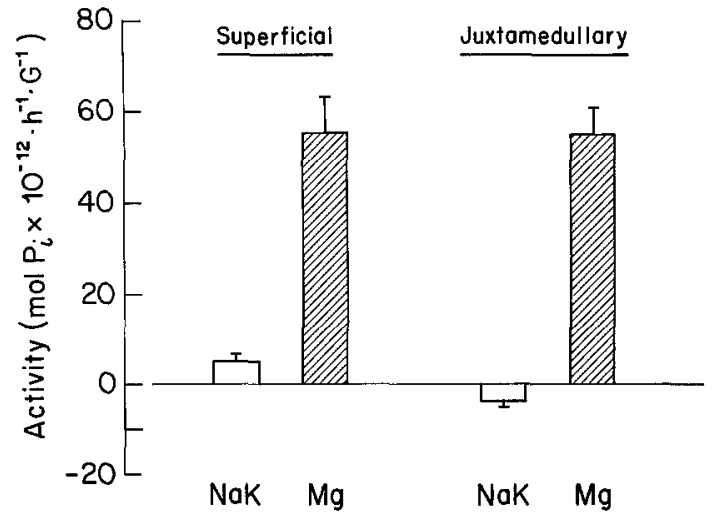

Fig. 3. Na-K- and Mg-ATPase activities in glomeruli (G) from superficial and juxtamedullary nephrons. Values shown are ATPase activities per glomerulus $\pm \mathrm{SE}$

of $9.1 \pm 2.03 \mathrm{pmol} \mathrm{P}_{\mathrm{i}} \cdot \mathrm{h}^{-1}(n=19) \mathrm{Na}-\mathrm{K}-\mathrm{ATPase}$ activity was calculated to average $7.1 \pm 2.98 \mathrm{pmol} \mathrm{P}_{\mathrm{i}} \cdot \mathrm{h}^{-1}$.

Photomicrographs were used to yield a morphological reference for data normalization. The mean volume of superficial macula densa segments used for total ATPase evaluation was $20,400 \pm 1,420 \mu^{3}$ and for Mg-ATPase measurements $19,000 \pm 1,130 \mu^{3}$. Corresponding numbers for juxtamedullary nephrons were $18,100 \pm 1,040 \mu^{3}$ and $19,000 \pm 1,560 \mu^{3}$. The lateral extension was approximately $50 \mu \mathrm{m}$ for both superficial and juxtamedullary macula densa segments used for either total or Mg-ATPase determinations.

Expressed as a function of sample volume, total ATPase activity and Mg-ATPase activity averaged $0.78 \pm 0.12 \mathrm{fmol}$ $\mathrm{P}_{\mathrm{i}} \cdot \mathrm{h}^{-1} \cdot\left(\mu \mathrm{m}^{3}\right)^{-1}$ and $0.41 \pm 0.07 \mathrm{fmol} \mathrm{P}_{\mathrm{i}} \cdot \mathrm{h}^{-1} \cdot\left(\mu \mathrm{m}^{3}\right)^{-1}$ respectively in superficial nephrons, and $0.89 \pm 0.1 \mathrm{fmol}$ $\mathrm{P}_{\mathrm{i}} \cdot \mathrm{h}^{-1} \cdot\left(\mu \mathrm{m}^{3}\right)^{-1}$ and $0.52 \pm 0.1 \mathrm{fmol} \mathrm{P}_{\mathrm{i}} \cdot \mathrm{h}^{-1} \cdot\left(\mu \mathrm{m}^{3}\right)^{-1}$ in juxtamedullary nephrons. Calculated average Na-K-ATPase per $\mu \mathrm{m}^{3}$ was identical for superficial $(0.37 \pm 0.21 \mathrm{fmol}$ $\left.\mathrm{P}_{\mathrm{i}} \cdot \mathrm{h}^{-1}\right)$ and juxtamedullary nephrons $(0.37 \pm 0.21 \mathrm{fmol}$ $\left.\mathrm{P}_{\mathrm{i}} \cdot \mathrm{h}^{-1}\right)$.

Results from microdissected glomeruli are summarized in Fig. 3. Total ATPase activity in superficial glomeruli averaged $60 \pm 7.0 \mathrm{pmol} \mathrm{P}_{\mathrm{i}} \cdot \mathrm{h}^{-1}$ and in juxtamedullary glomeruli $51.3 \pm 8.2 \mathrm{pmol} \mathrm{P}_{\mathrm{i}} \cdot \mathrm{h}^{-1}$ (NS). Mg-ATPase activity was $55.1 \pm 8.2 \mathrm{pmol} \mathrm{P}_{\mathrm{i}} \cdot \mathrm{h}^{-1}$ in superficial and $54.5 \pm 7.3 \mathrm{pmol} \mathrm{P}_{\mathrm{i}} \cdot \mathrm{h}^{-1}$ in juxtamedullary nephrons (NS). Na-K-ATPase was $4.9 \pm 1.86$ pmol $\mathrm{P}_{\mathrm{i}} \cdot \mathrm{h}^{-1}$ in superficial and $-3.2 \pm 1.86$ pmol $P_{i} \cdot h^{-1}$ in juxtamedullary nephrons, values not significantly different from zero.

The mean volume for superficial glomeruli was 143,800 $\pm 4,800 \mu^{3}$ (total ATPase) and $149,400 \pm 6,850 \mu \mathrm{m}^{3}$ (Mg-ATPase). In juxtamedullary nephrons we obtained a mean volume of $186,200 \pm 1,050 \mu \mathrm{m}^{3}$ for total and $192,900 \pm 11,400 \mu^{3}$ for Mg-ATPase measurements. These values were significantly greater than in superficial nephrons $(P<0.001)$. Total superficial glomerular ATPase activity per unit volume was $0.41 \pm 0.04 \mathrm{fmol} \mathrm{P}_{\mathrm{i}} \cdot \mathrm{h}^{-1} \cdot\left(\mu \mathrm{m}^{3}\right)^{-1}$ compared to $0.28 \pm 0.04 \mathrm{fmol} \mathrm{P}_{\mathrm{i}} \cdot \mathrm{h}^{-1} \cdot\left(\mu \mathrm{m}^{3}\right)^{-1}$ for juxtamedullary nephrons $(P<0.05)$. Mg-ATPase activity per unit volume was $0.37 \pm 0.05 \mathrm{fmol} \mathrm{P}_{\mathrm{i}} \cdot \mathrm{h}^{-1} \cdot\left(\mu \mathrm{m}^{3}\right)^{-1}$ in superficial nephrons and $0.28 \pm 0.04 \mathrm{fmol}_{\mathrm{i}} \cdot \mathrm{h}^{-1} \cdot\left(\mu \mathrm{m}^{3}\right)^{-1}$ in deep nephrons. 
Table 1. ATPase activities in macula densa cells from superficial and juxtamedullary nephrons and their relation to tissue mass

\begin{tabular}{|c|c|c|c|c|c|c|c|c|}
\hline & \multicolumn{4}{|l|}{ Superficial } & \multicolumn{4}{|c|}{ Juxtamedullary } \\
\hline & $>20,000$ & $n$ & $<20,000$ & $n$ & $>20,000$ & $n$ & $<20,000$ & $n$ \\
\hline Total ATPase & $17.7 \pm 4.0$ & 11 & $12.7 \pm 2.1$ & 9 & $21.1 \pm 4.9$ & 7 & $13.5 \pm 1.7$ & 13 \\
\hline Mg-ATPase & $10.4 \pm 1.9$ & 8 & $6.1 \pm 1.6$ & 10 & $12.7 \pm 3.7$ & 9 & $5.9 \pm 1.5$ & 10 \\
\hline Na-K-ATPase & $7.3 \pm 5.0$ & & $6.6 \pm 2.6$ & & $8.4 \pm 6.0$ & & $7.6 \pm 2.4$ & \\
\hline
\end{tabular}

ATPase activities are in $\mathrm{pmol} \mathrm{P}_{\mathrm{i}} \cdot \mathrm{h}^{-1} \cdot$ macula densa ${ }^{-1}$

\section{Discussion}

The present study applied a sensitive microenzymatic assay to the question of whether macula densa cells of rabbit kidney tubules possess a ouabain-sensitive ATPase activity in measurable quantities. From our results we conclude that such an enzyme is in fact present in these cells and that its activity is the same in superficial and juxtamedullary nephrons.

Since macula densa cells are surrounded by thick ascending limb (TAL) cells with a high Na-K-ATPase activity, the main technical problem in our study is to exclude contamination of the dissected tissue samples by non-macula densa cells. In a strict sense, definite proof for the purity of the analysed material cannot be given. However, two arguments would point to a negligible contribution of contaminating tissue to the measured Na-K-ATPase activity. Firstly, special care was taken to separate the macula densa cell plaque from the adjacent TAL cells in the early stages of the dissection when the macula cells were clearly distinguishable. Consequently, the average lateral extension of the dissected macula densa segments was between 49.5 and $51 \mu \mathrm{m}$, values which represent the normal diameter of the macula densa for the weight group used in this study (Kaissling and Kriz 1979). Separation of the macula densa cells towards the glomerulus proved to be a procedure which was more difficult to control. In fact, the average tissue surface areas for our analysed tissue was larger than estimated from ultramicrographs (Kaissling and Kriz 1979). In addition to the appearance, there is evidence in our data supporting the contention that any contamination was by glomerular rather than epithelial tissue. As has been shown earlier (Schmidt and Dubach 1974) and confirmed in this study, glomeruli contain substantial amounts of $\mathrm{Mg}$ ATPase, but are free of measurable quantities of the Na-dependent enzyme. Thus, if macula densa samples occasionally are contaminated by glomerular cells one would predict that total ATPase as well as Mg-ATPase should be higher in the larger tissue samples, while Na-KATPase should be independent of tissue mass. On the other hand, contamination by TAL cells should lead to tissue mass dependency of Na-K-ATPase. To test this, we have divided our samples into two arbitrary groups, those with tissue volumes greater or smaller than $20,000 \mu \mathrm{m}^{3}$. As can be seen in Table 1, in both superficial and deep nephrons total as well as $\mathrm{Mg}$-ATPase was dependent upon tissue volume while Na-K-ATPase was independent. This suggests strongly that the somewhat high tissue mass in some macula densa samples was due to the presence of cells lacking significant quantities of Na-K-ATPase.

Our conclusion that Na-K-ATPase is present in macula densa cells is in apparent contradiction to the only other systematic attempt to measure this enzyme in this particular
Table 2. Estimation of Na-K-ATPase activity per unit cell volume in specific segments along the rabbit nephron

\begin{tabular}{llll}
\hline & $\begin{array}{l}\text { Volume } / \mathrm{mm}^{\mathrm{a}} \\
\left(\mu \mathrm{m}^{3}\right)\end{array}$ & $\begin{array}{l}\mathrm{Na}-\mathrm{K}-\text { ATPase }^{\mathrm{b}} \\
\left(\mathrm{pM} \cdot \mathrm{h}^{-1} \cdot\right. \\
\left.\mathrm{mm}^{-1}\right)\end{array}$ & $\begin{array}{l}\mathrm{Na-K}-\mathrm{ATPase} \\
\left(\mathrm{fM} \cdot \mathrm{h}^{-1} .\right. \\
\left(\mu \mathrm{m}^{3}\right)^{-1}\end{array}$ \\
\hline PCT & 746,849 & 6,300 & 8.43 \\
PST & 518,359 & 1,380 & 2.66 \\
tALH & 130,670 & 180 & 1.38 \\
TAL $_{\mathrm{m}}$ & 547,252 & 7,440 & 13.59 \\
TAL $_{\mathrm{c}}$ & 137,868 & 1,860 & 13.49 \\
DCT & 640,778 & 9,120 & 14.23 \\
CNT & 600,470 & 7,560 & 12.59 \\
CCT & 557,025 & 1,380 & 2.48 \\
OMCT & 819,690 & 1,140 & 1.37 \\
MD & & & 0.37 \\
G & & & 0.03 \\
\hline
\end{tabular}

Abbreviations used: PCT proximal convoluted tubule, PST proximal straight tubule, tALH thin ascending limb of Henle's loop, TAL thick ascending limb of Henle's loop (m medullary, c cortical), DCT distal convoluted tubule, CNT connecting tubule, CCT cortical collecting tubule, OMCT outer medullary collecting tubule, $\mathrm{MD}$ macula densa, $\mathrm{G}$ glomerulus

a Calculated from Welling and Welling (1976) and Kaissling and Kriz (1979)

b From Garg et al. (1981)

cell group. Using a histochemical method Beeuwkes and Rosen (1980) failed to demonstrate Na-K-ATPase activity in macula densa cells using PNPP as a substrate even though heavy staining was seen in TAL cells. The simplest explanation for this discrepancy would be the assumption that macula densa cell $\mathrm{Na}-\mathrm{K}$-ATPase activity is below the detection limit of the histochemical PNPP-ase method. A comparison of our data with results reported for other nephron segments supports this assumption. This comparison is based on estimates of cellular areas derived from ultramicrographs from rabbit kidneys (Kaissling and Kriz 1979; Welling and Welling 1976) and the ATPase measurements of Garg et al. (1981). As can be seen in Table 2, enzyme-rich segments (cortical and medullary TAL, DCT, CNT) have a Na-KATPase activity of $10-15 \mathrm{fM} \mathrm{h}^{-1}\left(\mu \mathrm{m}^{3}\right)^{-1}$ while segments such as tALH or OMCT have an approximately tenfold lower activity of the enzyme. Our measurements show that $\mathrm{Na}-\mathrm{K}-\mathrm{ATP}$ ase activity of macula densa cells approaches that of the low-enzyme segments.

Existing information concerning the biochemical properties of the macula densa characterizes this cell group as a distinct nephron segment. In addition to the observed variations in $\mathrm{Na}-\mathrm{K}$-ATPase activity as indicated in this as well as in the Beeuwkes and Rosen study (1980), earlier work in rabbit and rat kidneys indicated that G6PDH activity was 
substantially higher in the macula densa cells than in the neighbouring cortical TAL and DCT (Hess and Gross 1959; Kazimierczak 1963; Norgaard 1979). On the other hand, the activity of several dehydrogenases of the Krebs cycle appears to be relatively low in the macula densa of rats (Krompecher-Kiss and Bucher 1977). The latter finding correlates with the reduced level of $\mathrm{Na}-\mathrm{K}$-ATPase since the activity of Krebs cycle enzymes correlates well with the level of Na-K-ATPase in distal nephron segments which rely on oxidative generation of ATP (Garg et al. 1981; Marver and Schwartz 1981). That the macula densa possesses certain unique biochemical aspects has recently also been documented by the observation that $\left[{ }^{3} \mathrm{H}\right]$-uridine labeling was strikingly higher in the macula densa than in all other tubular segments suggesting a high rate of RNA synthesis in these cells (Vandewalle et al, 1984). The technical feasibility of isolating macula densa segments as outlined in the study of Norgaard (1979) and in the present work should allow a further characterization of the biochemical properties of these cells.

It is experimentally well supported that the macula densa acts as a sensor element in the control of glomerular filtration rate by tubuloglomerular feedback and in renin secretion. Additional evidence has been interpreted to suggest that $\mathrm{NaCl}$ transport across the macula densa may affect both the response of the glomerular arterioles and the rate of renin secretion (Schnermann and Briggs 1982; Vander 1967). Since absorption of $\mathrm{NaCl}$ at this site would almost certainly proceed against an electrochemical gradient, the presence of Na-K-ATPase is required to make such a movement energetically feasible. Thus, while our results do not contribute to further substantiate transport dependency of tubuloglomerular feedback or renin secretion they seem to support the viability of this hypothesis.

In summary, by applying a microenzymatic assay we have demonstrated the presence of Na-K-ATPase in macula densa segments of both superficial and deep nephrons and its absence in associated glomeruli. Whether this enzyme is involved in transcellular transport and the processing of transduction signals across macula densa cells remains to be established.

Acknowledgements. The authors would like to thank Ms. Jeanne Snyder for use of the cryostat employed in these analyses and Dr. $H$. Helderman for the photographic equipment. These studies were supported by AM 21576 and AM 14677.

\section{References}

Beeuwkes R, Rosen S (1980) Renal Na-K-ATPase: localization and quantitation by means of its $\mathrm{K}$-dependent phosphatase activity.
In: Boulpaep EL (ed) Current topics in membranes and transport, vol 13. Academic Press, New York, pp 343-354

Doucet A, Katz AL, Morel F (1979) Determination of Na-KATPase activity in single segments of the mammalian nephron. Am J Physiol 237:F105-F113

Ernst SA (1972) Transport ATPase cytochemistry II. Cytochemical localization of ouabain-sensitive, K-dependent phosphatase activity in the secretory epithelium of the avian salt gland. $J$ Histochem Cytochem 20:23-28

Garg LC, Knepper MA, Burg MB (1981) Mineralocorticoid effects on Na-K-ATPase in individual nephron segments. Am J Physiol 240: F 536 - F 544

Hess R, Gross F (1959) Glucose-6-phosphate dehydrogenase and renin in kidneys of hypertensive or adrenalectomized rats. Am J Physiol 197:869-872

Kaissling B, Kriz W (1979) Structural analysis of the rabbit kidney. In: Advances in anatomy, Embryology and cell biology, vol 56. Springer, Berlin Heidelberg New York, pp 1-106

Kazimierczak J (1963) Histochemical study of oxidative enzymes in rabbit kidney before and after birth. Acta Anat 55:352-369

Krompecher-Kiss E, Bucher O (1977) Comparison of the activities of some dehydrogenases in the juxtaglomerular complex of kidneys of Wistar rats and desert rats (Meriones culati). Histochemistry 53:265-269

Lowry OH, Passonneau JV (1972) A flexible system of enzymatic analysis. Academic Press, New York, pp 86-92, 223-228, $254-255,259$

Marver D, Schwartz MJ (1980) Identification of mineralocorticoid target sites in the isolated rabbit cortical nephron. Proc Natl Acad Sci USA 77:3672-3676

Norgaard T (1979) Quantitative measurement of G6PDH in cortical fractions of the rabbit nephron. Histochemistry 63:103-113

Petty KJ, Kokko JP, Marver D (1981) Regulation of rabbit CCT Na-K-ATPase activity by aldosterone. J Clin Invest 68:15141521

Schmidt U, Dubach UC (1970) The behavior of Na-K-activated ATPase in various structures of the rat nephron after furosemide application. Nephron 7:447-458

Schmidt U, Schmidt H, Frank B, Dubach UC (1974) The function of Na-K-ATPase in single portions of the rat nephron. Ann NY Acad Sci 242:489-500

Schnermann J, Briggs JP (1982) Concentration-dependent sodium chloride transport of the signal in feedback control of glomerular filtration rate. Kidney Int 22:S82-S89

Vander AJ (1967) Control of renin release. Physiol Rev 47:359 382

Vandewalle A, Farman N, Cluzeaud F, Bonvalet J-P (1984) Heterogeneity of uridine incorporation along the rabbit nephron. I. Autoradiographic study. Am J Physiol 246:F417-F 426

Welling LW, Welling DS (1976) Shape of epithelial cells and intercellular channels in the rabbit proximal nephron. Kidney Int $9: 385-394$

Received July 3, 1985/Accepted February 17, 1986 